\title{
IAMJ
}

INTERNATIONAL

AYURVEDIC

MEDICAL JOURNAL

Review Article

ISSN: 2320-5091

Impact Factor: 6.719

\section{BIJA, BIJABHAGA AND BIJABHAGA-AVAYAVA ASSOCIATED WITH ANUVANSHIKI}

$\underline{\text { Mohini }}^{1}, \underline{\text { Sanjay Kumar Yadav }}{ }^{2}$, Sunita Kumari $^{3}$

${ }^{1}$ P.G. Scholar, Department of Rachana Sharir,

${ }^{2}$ P. G. Scholar, Department of Samhita \& Siddhanta,

State Ayurvedic College \& Hospital, Lucknow, U.P., India

${ }^{3}$ Reader, H.O.D., P.G. Department of Rachana Sharir, State Ayurvedic College \& Hospital, Lucknow, U.P., India

Corresponding Author: sanjay.yadavks3@gmail.com

https://doi.org/10.46607/iamj1309062021

(Published Online: June 2021)

Open Access

(C) International Ayurvedic Medical Journal, India 2021

Article Received: 19/05/2021 - Peer Reviewed: 09/06/2021 - Accepted for Publication: 10/06/2021

Check for updates

\section{ABSTRACT}

Ayurveda is one of the most ancient life sciences it is mentioned by acharyas that it is more ancient than man because it came earlier to earth. Being a life science there is description of how life came to origin, how to live life along with the description of various diseases under various disciplines. Here by Acharya Charak and Vriddha Vagbhatta-Bija, Bijabhaga and Bijabhaga-avayava is mention as three basic components of genetics, which are responsible for inheritance of various characteristics as well as for various diseases. The human genome project started in 1990 had aimed to identified human genetic coding of DNA, so that disease associated with genetic mutation or deletion can be prevented in their acute stage like cancer, leprosy, thalassemia, etc. In the same manner Acharyas also mention various diseases associated with bija, bijabhaga, bijabhaga-avayava dusti and transferred to next progeny. In this article we highlighted over the genetic defect of Secondary sexual development.

Keywords: Bija, Bijabhaga, Bijabhaga-avayava, dusti, Shukra, Shonita, etc.

\section{INTRODUCTION}

The concept of human genetics in Ayurveda are well known as Bija, Bijabhaga and Bijabhaga-avayava. These facts are responsible for defective progeny because dusti of Bija, Bijabhaga and Bijabhagaavayava leads to change into characteristics either in the form of its absence or their mal- presentation. 
According to Sir Monier William Bija means seed or gamete will is responsible for new offspring ${ }^{1}$. In Pratyakshashariram Bija is "Prajajananarathashamo dhatu" means which have the capacity to produce new offspring 2. Acharya Sushruta described Prameha, Kushtha, Sthaulya, etc. Bija dosha-janya Vikars. Except these there is description of various other Garbhaj Vikaras like-

- Eight type of Karmanusara Garbha vikriti i.e., Dwireta, Pawnendriya, Samsakaravahi, NarShanda-Nari Shanda, Vakri and Vatika Shanda ${ }^{3}$

- Purushvyapad evam starivyapada

- Bijopghatajanya klaibyata ${ }^{5}$

- Eight type of Garbhaj-gada- Upavishtaka, Nagodara, Makkala shola, Gunagarbha, Munagarbha, Vishkambha, Jarayudosha, Garbhapata etc. ${ }^{6}$

This article highlights over Garbhaj vikaras associated with dusti of bija. Bijabhaga and Bijabhaga-avayava.

\section{Aim and Objectives}

1. To understand Bija, Bijabhaga and bijabhagaavayava and correlation with its possible modern perspective of genetics.

2. To clarify what we can understood from dusti of bija-bijabhaga and bijabhaga-avayava and its possible modern correlation.

\section{Bija, Bijabhaga and Bijabhaga-avayava}

According to Acharya Charak Garbha is formed by fusion of Shukra-Shonita along with Jiva into Kukshi ${ }^{7}$ Bija is responsible for conception, here the ShukraShonita are the bija which can be compared with sperm and ova. Acharya Chakrapani States that "Bija iti Shukra-Shonite" means Shukra-Shonita are Bija and it acts as initiator for beginning of new life. The Bija of human is the community of every organ, which is the product of a male its own parts ${ }^{8 .}$ Bijabhaga is a part of bija which is responsible for formation of Shukra-rupi bija into body, it also carries information for development of Anga-pratayanga ${ }^{9}$. Bijabhagaavayava is a part of bijabhaga which is responsible for transmission of a character in a progeny.

\section{Dusti of Bija, Bijabhaga, Bijabhaga-avayava}

Bija dusti- If the bija gets vikrit then it will not be able for a new progeny ${ }^{10 .}$ Acharya Charak also have the same view. Acharya Sushruta described eight type of Shukra-dosha in Sharira-adhayaya-2. If both male and female bija gets completely destructed by kushtha, they will be incapable for new progeny but if the gets contaminated they will give birth to defective progeny only ${ }^{11 .}$

Bijabhaga dusti- Due to dusti of Bija along with Bijabhaga Vandhyata occurs to the offspring ${ }^{12 .}$ It can be correlated with chromosomal abnormalities because chromosomes are present into the bija and they carry the information for development.

Bijabhaga-avayava dusti- Its dusti causes janma of Putipraja or Varta i.e., a defective progeny who is sterile and along with other systemic illness, it may be due to defect in gene or due to gene mutation ${ }^{13 .}$

Sahaja Klaibyata- The word Klaibya represented as Impotency, it is a Latin word meaning lacking power specially required for copulation. Impotence defined as inability to sustain penile erection needed for copulation or inability to obtain ejaculation or both. There are four type of Klaibyata described by Acharya Charak one of them is Bijaopghata-janya klaibyata. It occurs due dusti of either mother or father Bija through vitiated vata which cause Shoshana of Retovaha sira of intrauterine foetus ${ }^{14 .}$

In modern it is also known as Erectile Dysfunction in which penis fails to erect during the sexual activity. It is of two types- primary ED and Secondary ED. Primary erectile dysfunction is the condition in which there is absence of full erection of penis since childhood. While the Secondary erectile dysfunction develops later on after a long period of time with normal erection ability. Sahaja Klaibyata can be correlated with Primary erectile dysfunction because in both condition person was never been able to achieve erection. Due to deficiency of Testosterone and Peyronie's disease, Congenital paraphimosis and phimosis are some conditions in which he is unable for proper erection.

Dwireta- In this condition the male and female shukra are present in equal quantity resulting offspring have equal characteristics of both sexes ${ }^{15}$. It can be compared with the condition of intersex which is a congenital condition in which Chromosomal, morphological and 
gonadal anomalies are present in the child. Such kind of individual have biological characteristics of both male and female sexes. There are mainly four cause of true hermaphrodites i.e.,

1. Complete androgen insensitivity

2. Partial androgen insensitivity

3. Congenital adrenal hyperplasia

4. 5-Alpha reductase deficiency

Pawanendriya- It is a condition in which vitiated vata cause destruction of Shukrashaya into intrauterine foetus ${ }^{16}$. It can be correlated the condition of Bilateral anorchia or vanishing testes syndrome. It is an extremely rare occurring condition which occurs due to failure of production of androgen by rudimentary gonads required for development of genitalia after $8^{\text {th }}$ week of intrauterine life. The children are XY karyotype but born without testes.

Samskarvahi -The vitiated vata causes vighattana of shukrashaya dwara ${ }^{17}$. This can be correlated with the condition of congenital male ductal system atresia.

Shandata- Due to Manda-alpa Bija of both male and female along with abala and Aharsh both partners involved in copulation and the product of conception will be kliba and it is of two types i.e., Nara-shanda and Nari-shanda ${ }^{18}$. It can be correlated with Y chromosome linked genetic defect, testicular dysgenesis Syndrome, etc. XXY (Klinefelter syndrome), XYY syndrome, XX male syndrome, etc.

Yonivyapada- Putraghni and Suchimukhi are due to contaminated female shukra while the Shandi is due to both defective male and female shukra ${ }^{19}$. The Putraghni yonivyapad can be correlated with Recurrent Miscarriage syndrome. Its most common cause is the abnormality in karyotype either in the foetus or in the gametes of mother father, remaining $50 \%$ cause includes uterine abnormality, Antiphospholipid syndrome, endocrine abnormality, etc.

The exact cause of Suchimukhi yonivyapad is not known yet. Shandi yonivyapad here also correlated with the intersex condition and Acharya Dalhana mention that both Shandi and Bandhya can have rudimentary or developed breast but both are contraindicated for copulation 20 .

\section{DISCUSSION}

Bija consist of Bijabhaga and bijabhaga-avayava which carries information for development of organ and system with expression of characteristics associated with them. Acharya clearly mentioned that if the bija is completely depraved then it will not be capable of new progeny. Because it will not be able to fertilize and form zygote. Bijabhaga resembles like chromosomes while Bijabhaga-avayava with gene in the cell. There are 23 pairs of chromosomes in human cell while the gametes carry 23 chromosomes. In human gamete Y-Chromosome decides whether the foetus will be male or female. Y-chromosome contains a gene i.e., SRY gene, it triggers development of male. But sometimes due to gene mutation as an effect of external factors results into defective expression or failure of expression of character into foetus. Gene mutation is the alteration in the sequence of DNA of a cell which can be occur due to inversion, deletion, insertion, translocation, etc. into the sequence of nucleotides resulting either formation of defective protein or Absence of protein formation.

Sahaja klaibyata caused by Bija dusti means demolition due to which SRY gene also affected resulting failure of male characteristics development in the foetus. Bijabhaga dusti indicates towards the Chromosomal abnormality, e.g.- In case of Dwireta there is defect in the Chromosome mainly resulting the following conditions. In complete androgen insensitivity syndrome, there is complete insensitivity of cell for androgenic hormones resulting failure of masculinization of male genitalia in developing foetus. The foetus present with both Müllerian duct and Wolffian duct. If the foetus has XY karyotype then due to defect in $\mathrm{Y}$ chromosome, there is failure of masculinization along with undescended testes. These are identified as Female. But in puberty there is female body pattern, breast development, along with short vagina that is a blind pouch with external genitalia. They are infertile. They neither have uterus, fallopian tubes nor have vas deferens, epididymis and seminal vesicle. They never menstruate also.

Partial androgen insensitivity syndrome is a defective genetic condition in which genital development of a 
foetus affected during intra-uterine life along with absence of secondary sex characteristics during puberty like if a child have normal karyotype of male then with partial androgen insensitivity he will present with spare body and facial hairs, slight breast development, undescended testes, small scrotum, clitoromegaly with hypospadias, Wolffian structures are partially developed. This occurs due to partial resistance of body tissues toward androgens.

Congenital adrenal hyperplasia is an autosomal recessive trait which occurs due to gene mutation resulting into deficiency of 21-hydroxylase which is responsible for steroidogenesis or production of mineralocorticoids, glucocorticoids or androgens (Sex hormones). Due deficiency of sex hormones male child presents with external female genitalia, in female child there will be clitoromegaly with hypospadias. Other symptoms will be vomiting due to deficiency of mineralocorticoids, ambiguous genitalia, early pubic hairs, precocious puberty, infertility, etc.

Here the 5-Alpha reductase deficiency can be correlated with Bijabhaga-avayava dusti. Because it occurs due to gene mutation cause alteration in protein synthesis resulting into deficiency of 5-Alpha reductase deficiency causing pseudovaginal perineoscrotal hypospadias in infants. The children at birth usually identified as female but at puberty there will be male secondary sexual characteristics appearance into them. All the bijabhaga and Bijabhaga-avayava dusti expression are similar because they occur due to defect either into a chromosome or defect in a particular fragment of chromosome i.e., gene.

\section{CONCLUSION}

The concept of Bija, Bijabhaga and Bijabhagaavayava indicated toward the acceptance of fundamental of modern genetics. Acharya indicating toward the inheritance of characteristics form one generation to other. If the Nidaan responsible for $d u s t i$ of Bija, Bijabhaga and Bijabhaga-avayava are alienated then a healthy progeny can be obtained. The bijabhaga and bijabhaga-avayava present in the Bija are responsible for inheritance and expression of traits. Hence, we can say that with proper knowledge of fundamental of bija, bijabhaga and bijabhaga-avayava congenital diseases as well as hereditary disease can be eliminated with the removal various nidana, it can be a further topic of study that how the fundamental of Ayurveda can be applicable in field of Contemporary Genetics.

\section{REFERENCES}

1. William S. M., Sanskrit-English Dictionary, New Edition, Printed by Great Britain At the University Press Oxford by Charles Batey printer to the University.

2. Sen G, Pratyaksha-shariram, A textbook of Human Anatomy in Sanskrit, Chukhamba Press, Krishnadas Ayurveda Series, Volume-1, Dwitiyoadhayaya, 2007.

3. Pandey K. 'Shastri', Dr. Chaturvedi G, Charak Samhita of Agnivesha, Vidhyotini Hindi commentary, Volume1, Sharirasthana-2, Atulyagotriyaadhayaya- 2/17, Chaukhambha Bharti Academy, Varanasi.

4. Pandey K. 'Shastri', Dr. Chaturvedi G 'Shastri', Charak Samhita of Agnivesha, Vidhyotini Hindi commentary, Volume-1, Sharirasthana-4, Mahatigarbhavakrantiadhayaya- 4/30-31, Chaukhambha Bharti Academy, Varanasi.

5. Pandey K. 'Shastri', Dr. Chaturvedi G 'Shastri', Charak Samhita of Agnivesha, Vidhyotini Hindi commentary, Volume-2, Chikitsa-sthana-2, Yonivyapadchikitsaadhayaya- 30/17, Chaukhambha Bharti Academy, Varanasi.

6. Sharma S. P., Sharangadhara Samhita, Subodhini Hindi commentary, Purvakhanda, Chapter-7, Rogagadanaadhayaya-7/180-181, Chaukhambha Amarbharti prakashana, Varanasi.

7. Pandey K. 'Shastri', Dr. Chaturvedi G., Charak Samhita, Vidhyotini Hindi commentary, Volume-1, Sharirasthana-4, Garbgavakranatiya-adhayaya- 4/5, Chaukhambha Bharti Academy, Varanasi.

8. Chakrapanidatta, Charak Samhita of Agnivesha, Ayurveda-dipika commentary, Sharirasthana-4, Mahatigarbhavakranti-adhayaya- 4/30, Satyabhamabai Panduranga Nirnayasagar publication, Bombay.

9. Chakrapanidatta, Charak Samhita of Agnivesha, Ayurveda-dipika commentary, Sharirasthana-3, Khuddikam-garbhavakrantriyaadhayaya- $\quad 3 / 17$, Satyabhamabai Panduranga Nirnayasagar publication, Bombay.

10. Dr. Shastri K. A., Sushruta Samhita, Ayurveda Tattva Sandipika Hindi commentary, Volume-1, Sharirasthana-2, Shudhashukrashonitasharira- 
adhayaya- 2/, Chaukhambha Sansktit Sansthan, Varanasi.

11. Dr. Shastri K. A., Sushruta Samhita, Ayurveda Tattva Sandipika Hindi commentary, Volume-1, Nidanasthana-5, Kusthanidana-adhayaya- 5/27, Chaukhambha Sansktit Sansthan, Varanasi.

12. Dalhana-acharya S., Sushruta Samhita, Nibandhasangraha commentary, Nidana-sthana-5, Kusthanidana-adhayaya- 5/27, Chaukhambha Surbharati Prakashan, Varanasi.

13. Pandey K. 'Shastri', Dr. Chaturvedi G., Charak Samhita of Agnivesha, Vidhyotini Hindi commentary, Volume1, Sharirasthana-4, Mahatigarbhavakranti-adhayaya4/30-31, Chaukhambha Bharti Academy, Varanasi.

14. Pandey K. 'Shastri', Dr. Chaturvedi G., Charak Samhita of Agnivesha, Vidhyotini Hindi commentary, Volume2, Chikitsa-sthana-30, Yonivyapadchikitsa-adhayaya30/189-190, Chaukhambha Bharti Academy, Varanasi.

15. Pandey K. 'Shastri', Dr. Chaturvedi G., Charak Samhita of Agnivesha, Vidhyotini Hindi commentary, Volume1, Sharirasthana-2, Atulyagotriyaadhayaya- 2/18, Chaukhambha Bharti Academy, Varanasi.

16. Pandey K. 'Shastri', Dr. Chaturvedi G., Charak Samhita of Agnivesha, Vidhyotini Hindi commentary, Volume1, Sharirasthana-2, Atulyagotriyaadhayaya- 2/18, Chaukhambha Bharti Academy, Varanasi.

17. Pandey K. 'Shastri', Dr. Chaturvedi G., Charak Samhita of Agnivesha, Vidhyotini Hindi commentary, Volume1, Sharirasthana-2, Atulyagotriyaadhayaya- 2/17, Chaukhambha Bharti Academy, Varanasi.

18. Pandey K. 'Shastri', Dr. Chaturvedi G., Charak Samhita of Agnivesha, Vidhyotini Hindi commentary, Volume1, Sharirasthana-2, Atulyagotriyaadhayaya- 2/19, Chaukhambha Bharti Academy, Varanasi.

19. Pandey K. 'Shastri', Dr. Chaturvedi G., Charak Samhita of Agnivesha, Vidhyotini Hindi commentary, Volume1, Sharirasthana-2, Atulyagotriyaadhayaya- 2/19, Chaukhambha Bharti Academy, Varanasi.

20. Dalhana-acharya S., Sushruta Samhita, Nibandhasangraha commentary, Uttar-tantra-, Yonivyapad-pratishedha-adhayaya- 38/18, Chaukhambha Surbharati Prakashan, Varanasi.

\section{Source of Support: Nil}

\section{Conflict of Interest: None Declared}

How to cite this URL: Sanjay Kumar Yadav et al: Bija, Bijabhaga And Bijabhaga-Avayava Associated With Anuvanshiki. International Ayurvedic Medical Journal \{online\} 2021 \{cited June, 2021\} Available from: http://www.iami.in/posts/images/upload/1232 1236.pdf 